\title{
Changes in body-weight, composition and hepatic enzyme activities in response to dietary methionine, betaine and choline levels in growing chicks
}

\author{
BY C. LINDA SAUNDERSON AND JAMES MACKINLAY \\ AFRC Institute for Grassland and Animal Production, Poultry Department, Roslin, \\ Midlothian EH25 9PS
}

(Received 19 June 1989-Accepted 10 October 1989)

\begin{abstract}
The experiments described here were set up (a) to investigate the effect of age and (b) to investigate the effect of giving five diets which varied in methionine and choline or betaine contents on some of the enzymes that metabolize these nutrients in chick liver. Growth and carcass composition of the chicks fed on the different diets were also examined. There was no obvious relationship between age and enzyme activity in young chicks. Only a diet low in methionine (but not one low in choline) showed a significant decrease in growth and a change in carcass composition. The effects of diet on enzyme activity were complex. Choline oxidase $(E C$ 1.1.3.17) activity was affected by the level of choline in the diet, being high when choline was present at high levels, especially when methionine was limiting. 5-Methyltetrahydrofolate homocysteine methyltransferase $(E C 2.1 .1 .3)$ had a high activity in the livers of chicks fed on a conventional diet compared with those given semi-purified diets. Other enzymes showed minor changes in response to the diet. The diet low in methionine showed a lower activity of cystathionine $\beta$ synthase $(E C 4.2 .1 .22)$ and slightly higher activities of methionine adenosyltransferase $(E C$ 2.5.1.6) and betaine-homocysteine methyltransferase ( $E C$ 2.1.1.5; compared with other diets), suggesting that this diet encouraged re-methylation of homocysteine at the expense of trans-sulphuration to cystathionine. The findings obtained in these studies form a useful basis for further investigation of the metabolic interrelationships between methionine and related nutrients.
\end{abstract}

Methionine: Choline: Betaine: Chickens

The essential amino acid methionine fulfils a number of important functions in metabolism. Apart from being a constituent of proteins, it has a unique role as the initiating amino acid of all polypeptide synthesis, it donates methyl groups in a number of important synthetic reactions, it is a precursor of the polyamines spermine and spermidine and its sulphur moiety can be used in the synthesis of cysteine.

The methylation role of methionine is fundamental to a number of areas of intermediary metabolism, e.g. amino acid metabolism, phospholipid synthesis, DNA and RNA synthesis and function, and is involved in numerous other pathways such as $C_{1}$ metabolism and creatine synthesis. Consequently methionine is known to interact with a number of other essential nutrients, the most obvious of these being cysteine (and sulphate), choline, vitamin $\mathrm{B}_{12}$ and folic acid. Interactions also exist with other amino acids such as arginine, glycine, serine and threonine (Keshavarz \& Fuller, 1971; Girard-Globa et al. 1972).

In order to investigate the nutritional interactions, information about the metabolism of the nutrients involved is required. The first step towards this is to measure how the activities of the enzymes involved change as the levels of the nutrients in the diet change. In the studies reported here, chicks were given one of five different diets varying in methionine or choline (or betaine) content for a period of $14 \mathrm{~d}$. Growth, food intake and carcass composition of the chicks were examined, and at the end of the experimental treatment some of the key enzymes of methionine-choline metabolism were assayed in liver tissues of 


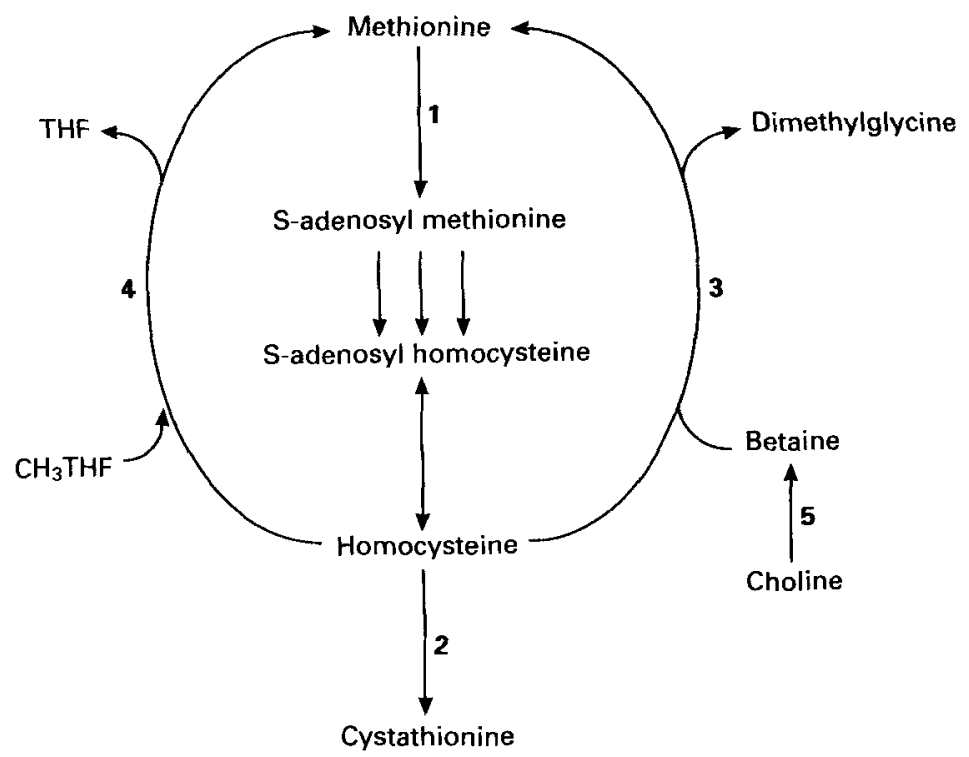

Fig. 1. Pathway linking methionine, choline and betaine metabolism in chick liver. The enzymes assayed are (1) methionine adenosyltransferase (EC 2.5.1.6); (2) cystathionine $\beta$-synthase (EC 4.2.1 22); (3) betaine-homocysteine methyltransferase $(E C 2.1 .1 .5)$; (4) 5-methyltetrahydrofolate methyltransferase $(E C 2.1 .1 .3)$; (5) choline oxidase (EC 3.1.1.27). THF, tetrahydrofolate; $\mathrm{CH}_{3} \mathrm{THF}$, methyltetrahydrofolate.

the chicks. The metabolic pathways of interest and the enzymes measured in the present study are indicated in Fig. 1.

\section{MATERIALS AND METHODS \\ Birds and husbandry}

Male broiler chicks were obtained at $1 \mathrm{~d}$ old (from D. B. Marshall, Newbridge, Midlothian) and placed in a heated battery brooder. Food and water were given ad lib. and the lighting regimen was $23 \mathrm{~h}$ light, $1 \mathrm{~h}$ dark.

\section{Chemicals and radiochemicals}

L- $\left[{ }^{14} \mathrm{CH}_{3}\right]$ methionine $(58 \mathrm{mCi} / \mathrm{mmol})$, [methyl- $\left.{ }^{3} \mathrm{H}\right]$ choline chloride $(56 \mathrm{mCi} / \mathrm{mmol})$, 5$\left[{ }^{14} \mathrm{C}\right]$ methyltetrahydrofolic acid $(60 \mathrm{mCi} / \mathrm{mmol})$ and $\mathrm{L}-\left[3-{ }^{14} \mathrm{C}\right]$ serine $(55 \mathrm{mCi} / \mathrm{mmol})$ were obtained from Amersham International plc, Amersham, Bucks. [Methyl- ${ }^{3} \mathrm{H}$ ]betaine was prepared from [methyl- ${ }^{3} \mathrm{H}$ ]choline chloride by the method of Xue \& Snoswell (1985). For the choline oxidase $\left(E C\right.$ 1.1.3.17) assay [methyl- $\left.{ }^{3} \mathrm{H}\right]$ choline chloride was further purified by chromatography using Dowex $50 \mathrm{~W}-\mathrm{X} 8$ ion-exchange resin $\left(\mathrm{Li}^{2+}\right.$ form, $\left.200-400 \mathrm{mesh}\right)$. Contaminants (principally betaine) were eluted with water, then the [methyl- $\left.{ }^{3} \mathrm{H}\right]$ choline was eluted in $2.5 \mathrm{M}$-hydrochloric acid. All other chemicals were obtained from Sigma Chemical Co. Ltd, Poole, Dorset or BDH Ltd, Poole, Dorset and were of the purest grade available. Reagents used were of analytical grade.

\section{Diets}

In Expt 1, a chick starter diet (as routinely used in this experiment) was given throughout the 4 weeks of study. This diet contained $(\mathrm{g} / \mathrm{kg})$ : maize 300 , wheat 245 , soya-bean meal 220 , barley 100 , herring meal 50 , grassmeal 50 , dicalcium hydrogen phosphate $21 \cdot 7$, limestone $5 \cdot 3$, sodium chloride $2 \cdot 5$, vitamins and minerals (according to Bolton \& Blair, 1974) 5.0. 
Table 1. Expt 2. Composition of the diets

\begin{tabular}{|c|c|c|c|c|c|}
\hline \multirow[b]{2}{*}{ Ingredient $(\mathrm{g} / \mathrm{kg})$} & \multicolumn{5}{|c|}{ Diet } \\
\hline & Control & $\mathbf{C M}$ & $\mathbf{B M}$ & $\mathbf{M}$ & $\mathrm{C}$ \\
\hline Maize meal & 330 & 400 & 400 & 400 & 400 \\
\hline Soya-bean meal & 280 & 50 & 50 & 50 & 50 \\
\hline Wheat meal & 250 & - & - & - & - \\
\hline Herring meal & 75 & - & - & - & - \\
\hline Extracted soya-bean protein (FP950)* & - & 170 & 170 & 170 & 170 \\
\hline Starch & - & 187 & 187 & 187 & 187 \\
\hline Lime & 15 & 12 & 12 & 12 & 12 \\
\hline $\mathrm{Ca}_{2} \mathrm{HPO}_{4}$ & 15 & 30 & 30 & 30 & 30 \\
\hline Salt & $2 \cdot 5$ & $3 \cdot 5$ & 3.5 & 3.5 & $3 \cdot 5$ \\
\hline Maize oil & $28 \cdot 0$ & $36 \cdot 5$ & $36 \cdot 5$ & $36 \cdot 5$ & 36.5 \\
\hline L-Tryptophan & - & 0.7 & 0.7 & 0.7 & 0.7 \\
\hline L-Lysine hydrochloride & - & 0.7 & 0.7 & 0.7 & 0.7 \\
\hline L-Cysteine & - & 0.5 & 0.5 & 0.5 & 0.5 \\
\hline Vitamins and minerals $\dagger$ & $5 \cdot 0$ & 5.0 & $5 \cdot 0$ & $5 \cdot 0$ & $5 \cdot 0$ \\
\hline Cellulose & - & 101 & 101.5 & 102 & 103 \\
\hline DL-Methionine & - & $2 \cdot 0$ & $2 \cdot 0$ & $2 \cdot 0$ & - \\
\hline Choline chloride $(50 \%)$ & - & $1 \cdot 2$ & - & - & $1 \cdot 2$ \\
\hline Betaine & - & - & 0.6 & - & - \\
\hline \multicolumn{6}{|l|}{ Analysis $(\mathrm{g} / \mathrm{kg})$} \\
\hline Crude protein $(\mathrm{N} \times 6.25)$ & $229 \cdot 4$ & $203 \cdot 1$ & 207.5 & $210 \cdot 6$ & $201 \cdot 3$ \\
\hline Oil & $55 \cdot 4$ & $54 \cdot 4$ & $55 \cdot 4$ & $54 \cdot 1$ & $54 \cdot 6$ \\
\hline Ash & 904 & 863 & 875 & 873 & 869 \\
\hline Dry matter & 904 & 863 & 875 & 873 & 869 \\
\hline Methionine & $5 \cdot 4$ & $5 \cdot 7$ & $5 \cdot 7$ & $5 \cdot 7$ & $3 \cdot 7$ \\
\hline Half cystine & $3 \cdot 3$ & $3 \cdot 0$ & $3 \cdot 0$ & $3 \cdot 0$ & $3 \cdot 0$ \\
\hline \multicolumn{6}{|l|}{ Calculated values } \\
\hline Choline $(\mathrm{mg} / \mathrm{kg})$ & 1300 & 1120 & 670 & 670 & 1120 \\
\hline Betaine $(\mathrm{mg} / \mathrm{kg}$ ) & - & - & 600 & - & - \\
\hline Metabolizable energy $(\mathrm{MJ} / \mathrm{kg})$ & $12 \cdot 6$ & $12 \cdot 7$ & $12 \cdot 7$ & $12 \cdot 7$ & $12 \cdot 7$ \\
\hline
\end{tabular}

* Interfood, Eastman Way, Hemel Hempstead, Herts.

$\uparrow$ As defined by Bolton \& Blair (1974) for starting chicks.

In Expt 2, five different diets were given. The composition of these is shown in Table 1. The control diet contained $230 \mathrm{~g}$ protein $/ \mathrm{kg}$ and no supplemental DL-methionine. The remaining four diets were derived from a common semi-purified basal mix which was calculated to be deficient in both methionine and choline. To this basal mix was added one of the following: choline + DL-methionine (CM), betaine + DL-methionine (BM), choline (C) or DL-methionine (M). The methionine content of diets was calculated from data of Blair et al. (1981) and choline content from Bolton \& Blair (1974). Crude protein (nitrogen $\times 6.25$ ), oil, ash and dry matter contents of diets were measured by standard procedures.

\section{Experimental protocol}

Expt 1. This experiment was set up to establish whether enzyme activities varied with the age of the chicks. Male broiler chicks were reared from $1 \mathrm{~d}$ old in a heated battery brooder. Four birds were taken at random at 1,2,3 and 4 weeks old, killed by cervical dislocation and livers and kidneys were rapidly excised, frozen and stored at $-20^{\circ}$. Samples of the livers were defrosted as required and enzyme activities were assayed as described below.

Expt 2. Chicks obtained at $1 \mathrm{~d}$ old were reared for 1 week in a heated battery brooder and given the control diet $a d$ lib. Chicks were then weighed and ten groups of ten birds (of equal mean weight) were placed (one group per cage) in a heated battery brooder. The five 
experimental diets were assigned at random, each to two groups of birds. Birds were weighed twice weekly and killed at $21 \mathrm{~d}$ of age by cervical fracture. Livers were rapidly removed, weighed, cut into pieces of approximately $1 \mathrm{~g}$ and stored at $-80^{\circ}$ until used for enzyme assay. All enzyme activities were measured in liver samples from the same group of ten birds for each diet. Where fewer than ten samples were assayed, these were chosen at random from the group. The muscles from one side of the breast and one leg were also carefully excised and weighed.

\section{Enzyme assays}

All incubations were performed at $40^{\circ}$ in a temperature-controlled water bath. Other procedures were performed at room temperature unless otherwise stated.

Radioactivity was measured using an LKB 1216 Liquid-scintillation spectrophotometer. Aqueous samples $(0.5 \mathrm{ml})$ were mixed with Optiphase X liquid-scintillation cocktail (Fisons Ltd, Loughborough) before counting.

Methionine adenosyltransferase (EC 2.5 .1 .6$)$. Liver samples $(0.5-1 \cdot 0 \mathrm{~g})$ were homogenized in 9 vol. ice cold potassium phosphate buffer, $0.03 \mathrm{M}$, pH 6.9 then centrifuged at $18000 \mathrm{~g}$ for $15 \mathrm{~min}$ at $0-4^{\circ}$. The supernatant fractions were assayed for enzyme activity. The assay method used was essentially that of Kotb \& Kredich (1985) except that the incubation contained ATP at $10 \mathrm{mM}$ and L-methionine at $0.5 \mathrm{~mm}$.

Betaine-homocysteine methyltransferase (EC 2.1.1.5). Liver supernatant fractions were prepared as described previously except that the potassium phosphate buffer was $0.04 \mathrm{M}$ and $\mathrm{pH} 7.5$. Samples of the supernatant fraction $(50 \mu \mathrm{l})$ were assayed for activity by a modification of the method of Finkelstein \& Mudd (1967) similar to that described by Skiba et al. (1982). In our system, the incubation mixture (total volume $0.35 \mathrm{ml}$ ) contained potassium phosphate ( $\mathrm{pH} \mathrm{7.4)} 25 \mu \mathrm{mol}$, homocysteine $2 \mu \mathrm{mol}$ and betaine $0.3 \mu \mathrm{mol}$ containing 250000 counts/min [methyl- ${ }^{3} \mathrm{H}$ ] betaine.

5-Methyl tetrahydrofolate $\left(\mathrm{CH}_{3} \mathrm{THF}\right)$ homocysteine methyltransferase (EC 2.1.1.3). The enzyme activity was extracted from liver tissue by the procedure of Mudd et al. (1970) and assayed by the method given in Xue \& Snoswell, (1985) except that the incubation mixture contained $0.6 \mu \mathrm{mol} \mathrm{CH}_{3} \mathrm{THF}$.

Cystathionine $\beta$-synthase (EC 4.2.1.22). The enzyme activity was extracted from liver tissue by the method of Selim \& Greenberg (1959) as described by Mudd et al. (1965). Enzyme activity was also measured according to Mudd et al. (1965), except that the final volume was $1.3 \mathrm{ml}$ and contained $3 \mu \mathrm{mol}$ pyridoxal phosphate, $0.175 \mu \mathrm{mol}$ cystathionine, $12.5 \mu \mathrm{mol}$ homocysteine and $120 \mu \mathrm{mol}$ serine containing 16650 counts $/ \mathrm{min} \mathrm{L}-\left[3-{ }^{14} \mathrm{C}\right] \mathrm{serine}$.

Choline oxidase (EC 1.1.3.17). Enzyme activity was assessed in liver homogenates prepared by gently dispersing $0.5 \mathrm{~g}$ liver using a Teflon pestle in $40.0 \mathrm{ml}$ potassium phosphate buffer $(0 \cdot 2 \mathrm{M}, \mathrm{pH} 7 \cdot 4)$, which was thoroughly gassed with oxygen-carbon dioxide $(95: 5, \mathrm{v} / \mathrm{v})$. Activity was measured as described by Xue \& Snoswell (1985) except that the final volume of reaction mixture was $3.025 \mathrm{ml}$ and choline was at $0.06 \mathrm{M}$ and contained $1.65 \mu \mathrm{Ci} / \mathrm{ml}\left[\right.$ methyl $\left.{ }^{3} \mathrm{H}\right]$ choline. In addition, the reaction was performed in an atmosphere of $\mathrm{O}_{2}-\mathrm{CO}_{2}(95: 5, \mathrm{v} / \mathrm{v})$ rather than pure $\mathrm{O}_{2}$.

Enzyme activities are expressed as $\mu \mathrm{mol}$ or $\mathrm{nmol} / \mathrm{h}$ per $\mathrm{mg}$ protein. Protein in enzyme and tissue samples was estimated using BCA protein reagent (Pierce (UK) Ltd, Cambridge) in an autoanalyser system (Bran \& Lubbe (TIS), Basingstoke, Hants). Bovine serum albumin was used as standard in the range $0.1-0.6 \mathrm{mg} / \mathrm{ml}$. Absorbance was read at $562 \mathrm{~nm}$.

\section{Carcass analysis}

Whole carcasses including feathers were roughly chopped into four pieces then minced finely. Representative samples (two per bird) were taken from the mince, weighed, freezedried and analysed for oil, ash and $\mathrm{N}$ using standard procedures. 
Table 2. Activities of methionine-metabolizing enzymes in broiler chicks aged 1-4 weeks (Mean values with their standard errors for duplicate determinations of the no. of animals indicated)

\begin{tabular}{|c|c|c|c|c|c|c|c|c|c|}
\hline \multirow{3}{*}{$\begin{array}{l}\text { Age (weeks) ... } \\
\text { Enzyme }\end{array}$} & \multirow[b]{3}{*}{$n$} & \multicolumn{8}{|c|}{ Activity ( $\mu \mathrm{mol} / \mathrm{h}$ per $\mathrm{g}$ wet liver) } \\
\hline & & \multicolumn{2}{|c|}{1} & \multicolumn{2}{|c|}{2} & \multicolumn{2}{|c|}{3} & \multicolumn{2}{|c|}{4} \\
\hline & & Mean & SEM & Mean & SEM & Mean & SEM & Mean & SEM \\
\hline $\begin{array}{l}\text { Methionine } \\
\text { adenosyltransferase } \\
(E C 2.5 .1 .6)\end{array}$ & 4 & $4 \cdot 64$ & $0 \cdot 31$ & $7 \cdot 31$ & 1.01 & $5 \cdot 25$ & $0 \cdot 36$ & $4 \cdot 28$ & $0 \cdot 26$ \\
\hline $\begin{array}{l}\text { Betaine-homocysteine } \\
\text { methyltransferase } \\
(E C \text { 2.1.1.5) }\end{array}$ & 4 & - & - & $3 \cdot 6$ & $0 \cdot 18$ & $2 \cdot 4$ & $0 \cdot 18$ & $3 \cdot 2$ & $0 \cdot 20$ \\
\hline $\begin{array}{l}\text { 5-Methyl tetrahydrofolate } \\
\text { homocysteine } \\
\text { methyltransferase } \\
(E C 2.1 .1 .3)\end{array}$ & 2 & - & - & $0 \cdot 68$ & -- & $0 \cdot 79$ & - & 0.58 & - \\
\hline $\begin{array}{l}\text { Cystathione } \beta \text {-synthase } \\
(E C 4.2 .1 .22)\end{array}$ & 2 & - & - & $16 \cdot 6$ & -- & $17 \cdot 3$ & - & $16 \cdot 9$ & - \\
\hline $\begin{array}{l}\text { Choline oxidase } \\
(E C 1.1 .3 .17)\end{array}$ & 2 & - & - & $400 \cdot 6$ & - & $394 \cdot 4$ & - & $384 \cdot 9$ & - \\
\hline
\end{tabular}

\section{Statistical treatment}

Effects of diet on body-weight, carcass composition and enzyme activities were compared by analysis of variance using a computerized statistical package (Minitab Inc., 215 Pond Laboratory, University Park, PA 16802, USA).

\section{RESULTS}

Expt 1

The enzyme activities measured in livers of broiler chicks aged 1-4 weeks are shown in Table 2. The results demonstrated that in this short age-range there was no obvious relationship between enzyme activity and age (or by inference, body-weight).

\section{Expt 2}

The growth of chicks (twenty per treatment) on the five dietary treatments is shown in Fig. 2 . The control diet produced by far the greatest weight gain $(P<0.05$ compared with all other diets). Chicks receiving diet $\mathrm{C}$ grew least well, although growth effects among diets $\mathrm{CM}, \mathrm{BM}, \mathrm{C}$ and $\mathrm{M}$ were not significant.

The mean body-weights, liver, leg and breast muscle weights of the birds used for the enzyme assays are shown in Table 3. These tissues showed an interesting pattern of growth. The liver weight of chicks given diet $\mathrm{CM}$ was significantly lower than that of chicks given the other diets $(P<0.05)$ and chicks given diets $\mathrm{BM}$ and $\mathrm{M}$ had lower liver weights than those given diet $\mathrm{C}(P<0.05)$. No differences in the protein concentration in livers of chicks fed on the five diets was found (results not shown). Chicks fed on the methionine-deficient diet $(C)$ had much less breast muscle $(P<0.05)$ than chicks given the other diets, but leg muscle was less for both diets $\mathrm{CM}$ and $\mathrm{C}$.

The carcass composition of the chicks sampled is shown in Table 4. Chicks given diet BM had lower body fat and higher protein $(\mathrm{g} / \mathrm{kg}$ body-weight) than the other treatments. This effect was significant for fat when compared with diet CM $(P<0.05)$ but not for protein 


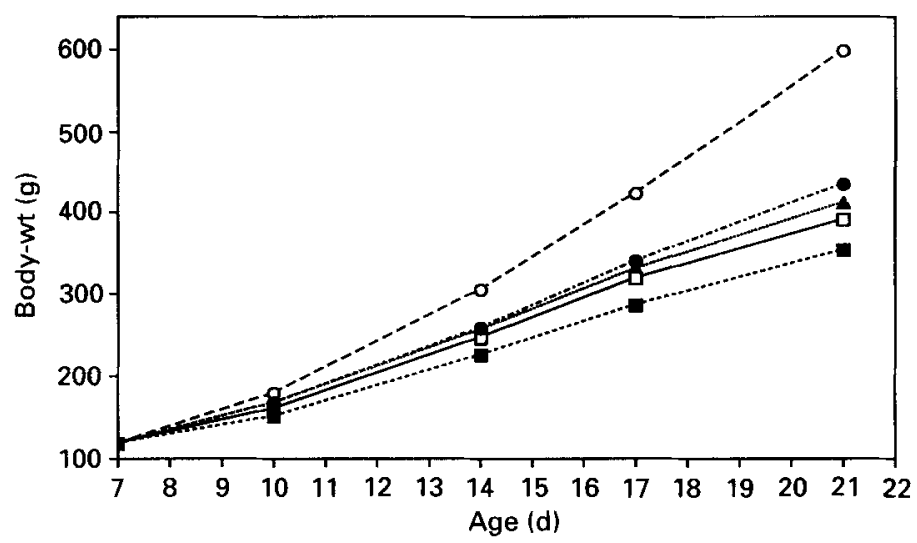

Fig. 2. Growth of chicks on the five experimental diets. For details of composition of the diets, see Table 1. Points represent mean values for twenty chicks on each diet. $(\mathrm{O}--\mathrm{O})$, Control $;(\boldsymbol{A} \boldsymbol{\Delta})$, basal + choline + methionine; $(\square-\square)$, basal + betaine + methionine ; $(\square--\square)$, basal + choline; $\left(\mathbf{O}_{-.-} \cdot \mathbf{0}\right)$, basal + methionine.

Table 3. Expt 2. Liver, muscle and body-weight values for chicks given different dietary treatments*

(Values are means for ten chicks per treatment)

\begin{tabular}{lcccc}
\hline Diet & $\begin{array}{c}\text { Body-wt } \\
(\mathrm{g})\end{array}$ & $\begin{array}{c}\text { Liver } \\
(\mathrm{g} / \mathrm{kg} \text { body-wt) }\end{array}$ & $\begin{array}{c}\text { Breast muscle } \\
(\mathrm{g} / \mathrm{kg} \text { body-wt })\end{array}$ & $\begin{array}{c}\text { Leg muscle } \\
(\mathrm{g} / \mathrm{kg} \text { body-wt) }\end{array}$ \\
\hline Control & $651 \cdot 9^{\mathrm{a}}$ & $26 \cdot 6^{\mathrm{ae}}$ & $49 \cdot 9^{\mathrm{a}}$ & $57 \cdot 8^{\mathrm{a}}$ \\
CM & $435 \cdot 6^{\mathrm{b}}$ & $22 \cdot 5^{\mathrm{b}}$ & $50 \cdot 1^{\mathrm{a}}$ & $53 \cdot 9^{\mathrm{b}}$ \\
BM & $419 \cdot 6^{\mathrm{b}}$ & $24 \cdot 6^{\mathrm{a}}$ & $47 \cdot 8^{\mathrm{a}}$ & $56 \cdot 1^{\mathrm{ab}}$ \\
M & $460 \cdot 4^{\mathrm{b}}$ & $24 \cdot 7^{\mathrm{a}}$ & $47 \cdot 3^{\mathrm{a}}$ & $56 \cdot 6^{\mathrm{a}}$ \\
C & $397 \cdot 7^{\mathrm{b}}$ & $26 \cdot 8^{\mathrm{c}}$ & $37 \cdot 6^{\mathrm{b}}$ & $53 \cdot 2^{\mathrm{b}}$ \\
Pooled SE (45 df) & $73 \cdot 50$ & $2 \cdot 31$ & $3 \cdot 66$ & $2 \cdot 96$ \\
\hline
\end{tabular}

a,b,c Means in each column, with different superscript letters were significantly different $(P<0.05)$.

$\mathrm{CM}$, basal + choline + DL-methione; BM, basal + betaine + DL-methionine; $\mathrm{M}$, basal + DL-methionine; C, basal -1 choline.

* For details, see p. 341.

Table 4. Expt 2. Carcass composition $(\mathrm{g} / \mathrm{kg})$ of chicks given different dietary treatments*

(Values are means of duplicate determination on six chicks per treatment)

\begin{tabular}{llrrr}
\hline Diet & Fat & Protein & Ash & Water \\
\hline Control & $84 \cdot 7^{\text {ab }}$ & $170 \cdot 3$ & $23 \cdot 8$ & $693 \cdot 5$ \\
CM & $88 \cdot 2^{\mathrm{a}}$ & $172 \cdot 8$ & $24 \cdot 3$ & $688 \cdot 2$ \\
BM & $71 \cdot 5^{\mathrm{b}}$ & $177 \cdot 3$ & $26 \cdot 5$ & $697 \cdot 2$ \\
M & $74 \cdot 3^{\mathrm{ab}}$ & $175 \cdot 2$ & $26 \cdot 0$ & $697 \cdot 2$ \\
C & $80 \cdot 5^{\mathrm{ab}}$ & $171 \cdot 2$ & $26 \cdot 8$ & $690 \cdot 2$ \\
Pooled SE $(25 \mathrm{df})$ & $13 \cdot 8$ & $6 \cdot 42$ & $2 \cdot 78$ & $13 \cdot 6$ \\
\hline
\end{tabular}

${ }^{a, b}$ Means with different superscript letters were significantly different $(P<0 \cdot 05)$.

$\mathrm{CM}$, basal + choline + DL-methionine; BM, basal + betaine + DL-methionine; $\mathrm{M}$, basal + DL-methionine; $\mathrm{C}$, basal + choline.

* For details, see p. 341 . 
Table 5. Activities of methionine-metabolizing enzymes in livers of chicks given different dietary treatments*

(Values are mean enzyme activities of no. of samples indicated. Activities are expressed as nmol/h per mg protein except for cystathionine $\beta$-synthase and choline oxidase which are expressed as $\mu \mathrm{mol} / \mathrm{h}$ per mg protein)

\begin{tabular}{|c|c|c|c|c|c|c|c|c|}
\hline \multirow[b]{2}{*}{ Enzyme } & \multirow[b]{2}{*}{$n$} & \multicolumn{5}{|c|}{ Diet } & \multirow[b]{2}{*}{ Pooled SE } & \multirow[b]{2}{*}{ df } \\
\hline & & Control & $\mathrm{CM}$ & BM & $\mathbf{M}$ & $\mathrm{C}$ & & \\
\hline $\begin{array}{l}\text { Methionine adenosyltransferase } \\
(E C \text { 2.5.1.6) }\end{array}$ & 8 & $57 \cdot 0^{\mathrm{ab}}$ & $57 \cdot 3^{\text {ab }}$ & $60 \cdot 5^{\mathrm{b}}$ & $49 \cdot 3^{\mathrm{a}}$ & $64 \cdot 9^{\mathrm{b}}$ & $11 \cdot 22$ & 35 \\
\hline $\begin{array}{l}\text { Betaine-homocysteine } \\
\text { methyltransferase }(E C 2.1 .1 .5)\end{array}$ & 10 & $24 \cdot 2^{\mathrm{ab}}$ & $25 \cdot 2^{\mathrm{ab}}$ & $22 \cdot 8^{\mathrm{a}}$ & $24 \cdot 4^{\mathrm{ab}}$ & $29 \cdot 5^{\mathrm{b}}$ & 6.54 & 45 \\
\hline $\begin{array}{l}\text { 5-Methyltetrahydrofolate } \\
\text { homocysteine methyltransferase } \\
(E C \text { 2.1.1.3) }\end{array}$ & 6 & $10 \cdot 3^{\mathrm{a}}$ & $5.6^{\mathrm{b}}$ & $5 \cdot 0^{\mathrm{b}}$ & $6 \cdot 3^{\mathrm{b}}$ & $6.7^{\mathrm{b}}$ & 2.49 & 25 \\
\hline $\begin{array}{l}\text { Cystathione } \beta \text {-synthase } \\
(E C 4.2 .1 .22)\end{array}$ & 6 & $1 \cdot 20^{\mathrm{ab}}$ & $1 \cdot 37^{\mathrm{a}}$ & $1 \cdot 24^{\mathrm{ab}}$ & $1.04^{\mathrm{ab}}$ & $1 \cdot 01^{b}$ & $0 \cdot 296$ & 25 \\
\hline Choline oxidase (EC 1.1.3.17) & 6 & $2 \cdot 59^{a}$ & $3 \cdot 37^{\mathrm{b}}$ & $2 \cdot 54^{\mathrm{a}}$ & $2 \cdot 17^{\mathrm{a}}$ & $6 \cdot 39^{c}$ & 0.566 & 25 \\
\hline
\end{tabular}

a,b,c Means in rows with different superscript letters were significantly different $(P<0.05)$.

* For details, see p. 341 .

compared with the control diet $(P<0 \cdot 1)$. The evident difference in ash concentration of birds on diets $C$ and control $(P<0.01)$ was due to the large difference in body-weight (growth) between these two groups. The activities of the enzymes methionine adenosyltransferase, betaine-homocysteine methyltransferase, $\mathrm{CH}_{3} \mathrm{THF}$ homocysteine methyltransferase, cystathionine $\beta$-synthase and choline oxidase in livers of chicks given the five different diets are shown in Table 5 .

The effects of the different diets are quite complex. Methionine adenosyltransferase activity was increased slightly by diet $\mathrm{C}$ and decreased on diet $\mathrm{M}$ compared with diets $\mathrm{CM}$, $\mathrm{BM}$ or control. Betaine-homocysteine methyltransferase showed only minor changes in response to dietary treatment. There was a small rise in activity with diet $\mathrm{C}$ compared with the other diets. Where betaine was included in the diet (BM), there was a small decrease in enzyme activity compared with the other diets.

$\mathrm{CH}_{3} \mathrm{THF}$ homocysteine methytransferase activity was unexpectedly high in livers of birds fed on the control diet $(P<0.01)$, and diets $\mathrm{C}$ and $\mathrm{M}$ also caused a slight increase in this enzyme compared with diets CM and BM.

Cystathionine $\beta$-synthase had a very high activity. When activities were translated into units per $g$ wet liver (results not shown) this enzyme was by far the most active of those enzymes using homocysteine as substrate. The activity was lower with both diets $\mathrm{C}$ and $\mathbf{M}$ compared with diet $\mathrm{CM}$.

Choline oxidase also had an extremely high activity compared with the other enzymes measured. The effects of dietary treatment on this enzyme were most interesting. Livers of chicks given diet $\mathbf{C}$ (methionine deficient) had a much higher activity of choline oxidase than with all other treatments $(P<0.001)$, while absence of added choline (diet $\mathrm{M}$ ) produced the lowest activity (diet $\mathrm{CM} v$. $\operatorname{diet} \mathrm{M} ; P<0.01$ ). Substituting betaine for choline in the diet lowered enzyme activity and diet $\mathrm{CM}$ produced a higher activity of choline oxidase than the control diet. 
DISCUSSION

Although only a short age-range was examined (1-4 weeks) there were no substantial changes in the activities of methionine and choline metabolizing enzymes with age (and hence body-weight). However, methionine adenosyltransferase and $\mathrm{CH}_{3} \mathrm{THF}$ homocysteine methyltransferase did decrease slightly between 2 and 4 weeks of age. The activities of these enzymes have been shown to decline with age in the liver of rats, albeit over a much wider age-range (Finkelstein, 1967; Finkelstein et al. 1971). Betaine-homocysteine methyltransferase and cystathionine $\beta$-synthase did not decline with age in chicks, but in rats betaine-homocysteine methyltransferase declines slightly over a wide age-range (Finkelstein et al. 1971) while cystathionine $\beta$-synthase increases with age (Finkelstein, 1967). There were no changes in the activity of choline oxidase between 2 and 4 weeks of age. Changes in the activity of this enzyme have been noted in sheep during the transition from weaning to the ruminant state (Xue \& Snoswell, 1986).

There could be a number of reasons why the control diet gave such better growth than diet CM in Expt 2. The higher protein concentration will have a positive effect on growth since the chicks were of a fast-growing broiler strain. We cannot rule out an amino acid deficiency in the semi-purified diets (CM, BM, C, M), although the diets were calculated to meet the requirements for all essential amino acids. There may also have been an effect of the physical nature of the food since the semi-purified diets have a powdery consistency and are perhaps less easy for the chicks to consume. Chicks given the semi-purified diets have a lower food intake than the control-fed birds (results not shown), although whether this led to or was a result of slower growth cannot be distinguished. The growth of the chicks given the control diet may also have been influenced by the fact that these birds suffered no change in the diet at the beginning of the experimental period since all chicks were reared from 1 to $8 \mathrm{~d}$ on the control diet.

It is noticeable that growth on the semi-purified diets did not differ greatly from one diet to another. This indicates that the degree of deficiency (of diets $C$ and $M$ ) is not large. The diets were primarily designed to examine the effects on the enzymes involved in metabolism of methionine, choline and betaine. However, the small effects on growth and body composition were useful in assessing the extent to which the metabolic changes were translated into body-weight and composition changes.

Where supplemental choline was replaced by betaine in the diet, there was no effect on growth of the chicks (Fig. 2). This would indicate that the requirement of the chicks for choline for functions other than methylation are being fully met in the basal diet. This would agree with the findings of Lowry et al. (1987) who suggested this requirement (for functions other than methylation) is $467+59 \mathrm{mg} / \mathrm{kg}$ for maximal growth in young chicks. Requirement for choline for all functions is much higher, especially where methionine is limiting and growth is faster (Pesti et al. 1980).

The proportion of body-weight that was liver in the chicks showed an interesting pattern of differences between diets. Comparing the semi-purified diets only, chicks given diet $\mathrm{C}$ had a much higher liver weight $(\mathrm{g} / \mathrm{kg}$ body-weight) than those given $\operatorname{diet} \mathrm{CM}$, while those given diets $M$ and $B M$ had intermediate liver sizes. Interpretation of these findings is difficult. This difference was not the result of changes in protein concentration in livers of chicks fed on the five diets. This suggests that the presence of methionine in the diet decreased liver size, while the effect of choline added to the diet appears to depend on whether or not methionine had also been added. Betaine had no apparent effect.

The proportion of body-weight that was breast or leg muscle in the chicks given the five different diets was fairly similar except for the breast and leg muscle of chicks given diet $\mathrm{C}$ and leg muscle of chicks given diet CM. Breast muscle has previously been shown (Bryan, 
1985; Saunderson \& Leslie, 1989) to be more sensitive than other tissues to lower protein (amino acid) supply. The slower growth of breast and leg muscle in these chicks may also reflect a less mature stage of development of the birds. Although both types of muscle grow rapidly in young broiler chicks there is an accelerated growth of breast muscle compared with leg muscle around this age (Saunderson \& Leslie, 1988).

Carcass composition also showed one interesting difference among the dietary treatments. Chicks given diet BM had a higher protein and lower fat concentration $(\mathrm{g} / \mathrm{kg}$ body-weight) than those given other treatments. Although the methylation function of methionine and choline is known to interact with fat metabolism (Percival et al. 1970; Fau et al. 1980), there is no obvious reason why betaine should have this effect on the composition of growth while lack of choline (diet M) does not. This phenomenon requires further investigation.

The activities of the enzymes measured in the present study (Table 5) were generally of a similar magnitude to the activities of these enzymes in rat liver (Finkelstein et al. 1971; Finkelstein \& Martin, 1986) and, with the exceptions of betaine-homocysteine methyltransferase, $\mathrm{CH}_{3}$ THF homocysteine methyltransferase and choline oxidase, in sheep tissues (Radcliffe \& Egan, 1974; Xue \& Snoswell, 1986). The activity of choline oxidase was also somewhat higher than that reported for rat liver by Xue \& Snoswell (1986), but similar to that found by Zeisel \& Wurtman (1981) for 40-d-old rats. Such differences can be accounted for by the different cell preparations and conditions used to measure activity in the various studies. As evident from Table 5, the activity of choline oxidase also changes with the choline content of the diet.

The effects of dietary treatment on the activity of the enzymes assayed are complex. There were only two significant differences in enzyme activity between the control diet and diet $\mathrm{CM}$, in choline oxidase and $\mathrm{CH}_{3} \mathrm{THF}$ homocysteine methyltransferase. The very significantly higher activity of $\mathrm{CH}_{3} \mathrm{THF}$ homocysteine methyltransferase in chicks fed on the control diet was unexpected. $\mathrm{CH}_{3} \mathrm{THF}$ homocysteine methyltransferase is an integral part of the tetrahydrofolate $\mathrm{C}_{1}$ metabolism system in liver. This metabolic pathway provides two of the $\mathrm{C}$ atoms for the synthesis of uric acid, the principal mechanism of $\mathrm{N}$ excretion in birds, and is a major route of catabolism of the amino acids glycine, serine and histidine. Since there are a number of ways in which the control diet differed from the other diets, it is difficult to determine any one aspect that may have caused the differences in $\mathrm{CH}_{3}$ THF homocysteine methyltransferase. It is interesting to note, however, that the activity of $\mathrm{CH}_{3}$ THF homocysteine methyltransferase never approaches that of betainehomocysteine methyltransferase, suggesting that -in chicks as in rats-re-methylation of homocysteine to methionine is principally accomplished by transfer of a methyl group from betaine.

Comparing enzyme activities in the semi-purified diets only, many differences are evident. There were a number of minor effects when choline was replaced by betaine (diet BM compared with diet $\mathrm{CM}$ ). There was a slight rise in methionine adenosyltransferase activity and slight decreases in betaine-homocysteine methyltransferase, $\mathrm{CH}_{3} \mathrm{THF}$ homocysteine methyltransferase, cystathionine $\beta$-synthase and choline oxidase. As expected, the choline oxidase activity was lower (diet BM $v$. diet $\mathrm{CM}, P<0.05$ ) indicating that the presence of choline in the diet activated or induced this enzyme, whereas betaine had no effect or perhaps inhibited the enzyme activity.

When diet $M$ ('choline deficient') was compared with diet $\mathrm{CM}$ there was a non-significant decrease in methionine adenosyltransferase and cystathionine $\beta$-synthase $(P<0 \cdot 10)$, a significant decrease in choline oxidase $(P<0 \cdot 01)$, and a slight increase in $\mathrm{CH}_{3}$ THF homocysteine methyltransferase. No study of a similar nature has been reported for other species, but studies where excess methionine was given to rats showed increases 
in methionine adenosyltransferase, betaine-homocysteine methyltransferase, cystathionine $\beta$-synthase and cystathionase (EC 4.4.1.1) with a corresponding decrease in $\mathrm{CH}_{3} \mathrm{THF}$ homocysteine methyltransferase (Fau et al. 1980; Finkelstein \& Martin, 1986). Thus, it appears that the effects of diet $M$ are not the same as in methionine excess, indicating that methionine and choline have an interacting effect on metabolism. Moreover, since diet $\mathbf{M}$ does not decrease growth compared with diet $\mathrm{CM}$, the adjustments made in the metabolism of methionine and choline must be adequate to support maximal potential growth on the semi-purified diet.

Compared with diet $\mathrm{CM}$, diet $\mathrm{C}$ (methionine deficient) produced the following changes in activity: increases (not significant) in methionine adenosyltransferase, betaine-homocysteine methyltransferase and $\mathrm{CH}_{3}$ THF homocysteine methyltransferase, a significant increase in choline oxidase, and a significant decrease in cystathionine $\beta$-synthase. Adding choline to a choline-free or low-choline diet has been shown to increase betaine-homocysteine methyltransferase in rat liver (Finkelstein et al. 1983), but effects on other enzymes have not previously been noted. The overall effect of these changes is to imply that there is a substantial increase in methyl group cycling and a relative decrease in conversion of homocysteine to cystathionine (compared with chicks fed on diet CM). This suggests that the system is adapting to catabolize excess choline (methyl groups), and to conserve available methionine by restricting conversion to cystathionine (cysteine). Growth of the chicks fed on diet $\mathrm{C}$ was slightly depressed and breast muscle content was lower than those fed on diet CM, suggesting that methionine was not being conserved well enough to support maximal growth (for the semi-purified diets).

Although these studies provide useful information towards a clearer understanding of the metabolic interactions between methionine and related nutrients, the effects of the dietary treatments on the operation of the entire system are difficult to appreciate without further investigation. Measurement of the tissue activities of the enzymes alone does not give enough information. Effects of substrate and cofactor levels, inhibitors and activators must all be taken into account. Finkelstein \& Martin $(1984,1986)$ rather elegantly demonstrated this using a complex reconstituted system of enzymes from rat liver. We are using the findings from the studies reported here to investigate the interaction of methionine and choline (betaine) metabolism using computer-simulation modelling techniques (McMinn \& Ottaway, 1976, Ottaway, 1979). These studies will be the subject of future publications.

We conclude that dietary content of methionine and choline does affect the hepatic levels of activity of the enzymes metabolizing these nutrients. There is, therefore, good reason to believe that further studies on these enzyme systems will be of use in investigation of interactions involving methionine, choline and related nutrients.

The authors are grateful to $\mathrm{Mr} \mathrm{S}$. Leslie for assistance in the planning and performance of some of these experiments and to Mrs C. C. McCorquodale for advice on statistical analyses. Financial assistance from AEC Société de chemie organique et biologique (now Rhone Poulenc Animal Nutrition), 03600 Commentry, France, and Finnsugar Ltd, Helsinki, Finland, in partial support of this work is gratefully acknowledged.

\section{REFERENCES}

Blair, J. C., Harber, C. D., McNab, J. M., Mitchell, G. G. \& Scougall, R. K. (1981). Analytical Data of Poultry Feedstuffs, 1977-1980. Occasional Publication no. 1. Roslin, Midlothian: ARC Poultry Research Centre. Bolton, W. \& Blair, R. (1974). Poultry Nutrition, Bulletin no. 174, 4th ed. London: H.M. Stationery Office. Bryan, L. (1985). Protein deposition in poultry. PhD Thesis, University of Nottingham.

Fau, D., Bois-Joyeux, B., Delhomme, B., Chanez, M. \& Peret, J. (1980). Long term effects of methionine excess on rat metabolism. Nutrition Reports International 21, 577-585. 
Finkelstein, J. D. (1967). Methionine metabolism in mammals: effects of age, diet and hormones on three enzymes of the pathway in rat tissues. Archives of Biochemistry and Biophysics 122, 583-590.

Finkelstein, J. D., Kyle, W. E. \& Harris, B. J. (1971). Methionine metabolism in mammals: regulation of homocysteine methyltransferase in rat tissues. Archives of Biochemistry and Biophysics 146, 84-92.

Finkelstein, J. D. \& Martin, J. J. (1984). Methionine metabolism in mammals: distribution of homocysteine between competing pathways. Journal of Biological Chemistry 259, 9508-9513.

Finkelstein, J. D. \& Martin, J. J. (1986). Methionine metabolism in mammals: adaptation to methionine excess. Journal of Biological Chemistry 261, 1582-1587.

Finkelstein, J. D., Martin, J. J., Harris, B. J. \& Kyle, W. E. (1983). Regulation of hepatic betaine homocysteine methyltransferase by dietary betaine. Journal of Nutrition 113, 519-521.

Finkelstein, J. D. \& Mudd, S. H. (1967). Transsulfuration in mammals : methionine sparing effects of cystine. Journal of Biological Chemistry 242, 873-880.

Girard-Globa, A., Robin, P. \& Forestier, M. (1972). Long term adaptation of weaning rats to high dietary levels of methionine and serine. Journal of Nutrition 102, 209-218.

Keshavarz, K. \& Fuller, H. L. (1971). Relationship of arginine and methionine to creatine formation in chicks. Journal of Nutrition 101, 855-862.

Kotb, M. \& Kredich, N. M. (1985). S-adenosyl methionine synthetase from human lymphocytes. Journal of Biological Chemistry 260, 3923-3930.

Lowry, K. R., Izquierdo, O. A. \& Baker, D. H. (1987). Efficacy of betaine relative to choline as a methyl donor. Poultry Science 66, Suppl. 1, 135.

McMinn, C. L. \& Ottaway, J. H. (1976). On the control of enzyme pathways. Journal of Theoretical Biology 56, 57-73.

Mudd, S. H., Finkelstein, J. D., Irreverre, F. \& Laster, L. (1965). Transsulfuration in mammals : microassays and tissue distributions of three enzymes in the pathway. Journal of Biological Chemistry 240, 4382-4392.

Mudd, S. H., Levy, H. L. \& Morrow, G. (1970). Deranged $\mathbf{B}_{12}$ metabolism: Effects on sulfur amino acid metabolism. Biochemical Medicine 4, 193-214.

Ottaway, J. H. (1979). Simulation of metabolic events. In Techniques in Metabolic Research B219, pp. 1-27 [H. L. Kornberg, J. C. Metcalfe, D. H. Northcote, C. I. Pogson and K. F. Tipton, editors]. Amsterdam : Elsevier/ North Holland Scientific Publishers.

Percival, G. S., Dunn, S. H., Howe, J. M. \& Clark, H. E. (1970). Interaction between methionine, fat and choline in the growing rat. Journal of Nutrition 100, 664-670.

Pesti, G. M., Harper, A. E. \& Sunde, M. L. (1980). Choline/methionine nutrition of starting broiler chicks. Three models for estimating the choline requirement with economic considerations. Poultry Science 59, 1073-1081.

Radcliffe, B. C. \& Egan, A. R. (1974). A survey of methionine adenosyltransferase and cystathionine $\gamma$-lyase activities in ruminant tissues. Australian Journal of Biological Science 27, 465-471.

Saunderson, C. L. \& Leslie, S. (1988). Muscle growth and protein degradation during early development in chicks of fast and slow growing strains. Comparative Biochemistry and Physiology 89A, 333-337.

Saunderson, C. L. \& Leslie, S. (1989). Cathepsin B, D and H activities in muscles of chicks of fast and slow growing strains: effect of age and diet. Comparative Biochemistry and Physiology 92A, 305-311.

Selim, A. S. M. \& Greenberg, D. M. (1959). An enzyme that synthesises cystathionine and deaminates L-serine. Journal of Biological Chemistry 234, 1474-1480.

Skiba, W. E., Taylor, M. P., Wells, M. S., Magnum, J. H. \& Awad, W. M. (1982). Human hepatic methionine biosynthesis: Purification and characterisation of betaine homocysteine S-methyltransferase. Journal of Biological Chemistry 257, 14944-14948.

Xue, G.-P. \& Snoswell, A. M. (1985). Comparative studies on the methionine synthesis in sheep and rat tissues. Comparative Biochemistry and Physiology 80B, 489-494.

Xue, G.-P. \& Snoswell, A. M. (1986). Developmental changes in the activities of enzymes related to methyl group metabolism in sheep tissues. Comparative Biochemistry and Physiology 83B, 115-120.

Zeisel, S. H. \& Wurtman, R. J. (1981). Developmental changes in rat blood choline concentration. Biochemical Journal 198, 565-570. 